IRSH 53 (2008), pp. 425-457 doi:I0.1017/S0020859008003556

(C) 2008 Internationaal Instituut voor Sociale Geschiedenis

\title{
Occupational Mobility and Internal Labour Markets: Public Sector Workers' Struggles in Bangalore (c. I960-1980)*
}

\author{
D IL I P S U R A M A N A N
}

SUMMARY: Instead of seeking to conceptualize internal labour markets as either exclusively facilitating employers' drive for greater workplace efficiency or reinforcing the contractual rights of workers, it would be more productive to recast them as institutions inherently ambivalent in character, and hence equally capable of serving the interests of both sides. This also implies that formalized career structures are not always the unilateral creations of employers intent on forging a compliant and diligent workforce, as radical labour academics tend to suggest. The agentic role of workers and unions in fighting to establish a codified framework of employment rules needs to be recognized as well, given the effectiveness of such rules in protecting labour from the arbitrary exercise of managerial power. Procedures governing seniority entitlements and promotion opportunities can again both operate as a unifying and a divisive force. Underscoring anew their ambivalence, they have the potential as much to mobilize workers as to fracture them along generational, skill, and ascriptive lines.

An important development common, but not exclusive, to large corporations, both private and publicly-owned, in the developed economies, from roughly the turn of the last century until the late i970s, has been the emergence of stable career paths for blue- and white-collar workers. ${ }^{\text {I }}$ Employers, acting either alone or in concert with unions, have devised on-the-job training and apprenticeship programmes designed to promote

\footnotetext{
* This essay is drawn from a chapter of my doctoral dissertation, "Usine Indienne. Travail, firme et société dans l'entreprise d'État Indian Telephone Industries (Bangalore, 1948-2006)", École des Hautes Études en Sciences Sociales, Paris, 2007. For the purpose of my dissertation, detailed tape-recorded interviews were conducted with close to ninety individuals, comprising management executives, union officials, technical personnel, and blue- and white-collar workers employed in all divisions of the Bangalore plant of ITI. The discussions covered a wide range of topics, including occupational mobility, excerpts from which have been utilized here. The interviews were held over a period of seven years from 1997 to 2004. All but two of the interviewees cited in this paper figured on the company's payrolls during the years when the agitation for seniority rights periodically erupted.

I. This essay has benefited tremendously from the generous and discerning critiques by two anonymous reviewers for IRSH as well as the editorial committee of the journal.
} 
skill acquisition, charted well-codified job ladders to govern promotions, recognized the legitimacy of seniority rights, and framed rules to oversee lay-offs, reinstatements, and intra-firm transfers, all these structural arrangements serving to articulate and define the "modern" work career. Scholars, particularly economists, have coined the term "internal labour market" to designate this institutional innovation, thus clearly contrasting it to the external labour market. In their influential book, Internal Labor Markets and Manpower Analysis, Peter Doeringer and Michael Piore state that internal labour markets are characterized by the rigidity of their administrative rules and procedures which accord to workers certain rights and privileges not available to the external labour force. ${ }^{2}$

With the visible hand of management having replaced the invisible hand of market forces in large multi-unit enterprises by establishing centralized mechanisms for the purpose of efficiently allocating resources, coordinating production flows, the supply of inputs, and the distribution of finished goods, it only stood to reason that labour transactions too became enmeshed in the same integrating drive. ${ }^{3}$ For employers confronted with the costs of high turnover, especially in the case of those operating in non-cyclical product markets, holding out the promise of steady upward professional mobility together with rewards for service tenure constituted a valuable arm in combating this perennial problem.

The importance of structured career trajectories in inculcating a sense of loyalty to the company was accentuated by the imperatives of standardized mass-production techniques, which being essentially dependent on semiskilled hands to run specialized machinery, made the development of firmspecific skills indispensable. The burden of shouldering training costs had to be borne solely by employers, and recouping these investments could only be achieved by retaining workers for long periods of time. ${ }^{4}$ Some authors have attributed the spread of internal labour markets to the consolidation of unionization as well. Union contracts not only often gave weight to formal requirements for training and experience; in a bid to pre-empt arbitrary actions by company managers and foremen, they also laid down elaborate written procedures for administering promotions and dismissals of workers. ${ }^{5}$

2. Peter Doeringer and Michael Piore, Internal Labor Markets and Manpower Analysis (Lexington, MA, I97I), pp. 2-6.

3. Alfred D. Chandler Jr, The Visible Hand: The Managerial Revolution in American Business (Cambridge, MA, I977), pp. I-I 2.

4. Laura Owen, "An Economic Perspective on Career Formation", in David Mitch et al. (eds), Origins of the Modern Career (Aldershot, 2004), pp. 42-55. For a useful account of the origins of formal career structures, see also in the same volume the essay by John Brown et al., "The History of the Modern Career: An Introduction”, pp 3-4I; and Sanford Jacoby, Employing Bureaucracy: Managers, Unions, and the Transformation of Work in American Industry, 1900-1945 (New York, 1985), ch. 8.

5. Brown, "The History of the Modern Career", p. I3. 
Much like their neo-classical counterparts, though not for quite the same reasons, radical academics who have engaged with this system of industrial jurisprudence have reacted to its advent with marked lack of enthusiasm. But their accounts tend to depict a rather one-sided picture. For instance, a historian like Richard Edwards takes care to present the workplace as a "contested terrain", analysing the evolution in the various types of control systems governing the social relations of production as a response in part to endemic conflict between capital and labour. ${ }^{6}$ Nevertheless, the rise of internal labour markets is viewed exclusively from the standpoint of managerial efficiency and the imperatives of profitability, leading him to conclude that they constitute a highly effective instrument in forging a compliant and individualized workforce. That workers could be the agens movens in building such regulatory institutions, and that they stood to gain as well from the existence of these institutions, is something he totally glosses over.

Similarly, emphasizing the importance of structured internal systems of labour management, Michael Burawoy describes them as forming one of the three foundational pillars (the other two being collective bargaining and the grievance-dispute machinery), upon which rests the edifice of the "internal state" whose function is to coordinate the interests of management and labour. ${ }^{7}$ Yet, he also tends both to downplay the active involvement of workers in the development of internal labour markets as well as to undervalue those features which advance the interests of the workforce. Instead, he prefers to concentrate on the negative, that is the divisive, individualizing, class-collaborative dimensions of promotion and seniority rules. Imparting renewed explanatory vigour to these management-centred interpretations has been the application of Foucauldian concepts of surveillance and capillary power to career structures. ${ }^{8}$

In contrast to both Edwards and Burawoy, Robert Castel provides us with an alternative, more sympathetic, reading which stresses the beneficial impact exercised by intra-firm labour transactions on workers' lives. Positing that contractual provisions aimed at the establishment of seniority rights guaranteed a measure of employment security, he argues that such regulations, by rendering wage labour more reliable and stable, also turned it in to a relatively attractive means of gaining one's livelihood. ${ }^{9}$

6. Richard Edwards, Contested Terrain: The Transformation of the Workplace in the Twentieth Century (New York, 1979), ch. 8. See also David Gordon et al., Segmented Work, Divided Workers: The Historical Transformation of Labor in the United States (Cambridge, 1982), pp. I 86-90.

7. Michael Burawoy, Manufacturing Consent (Chicago, IL, I979), pp. I9, I 10-1 20.

8. Andrew Miles and Mike Savage, "Constructing the Modern Career", in Mitch, Origins of the Modern Career, pp. 79-100.

9. Robert Castel, Les métamorphoses de la question sociale (Paris, 1995), pp. 523-54I. 


\section{AMBIVALENT CHARACTER OF INTERNAL LABOUR MARKETS}

Though the position defended in this paper leans more in the direction of the explanation suggested by Castel, it also seeks to transcend the conventional binary framework where internal labour markets are either understood as exclusively strengthening the command prerogatives of employers or the bargaining power of workers. Based on a study of worker and union protest from the early i960s until the end of the I970s at a state-owned company manufacturing telecommunications equipment, Indian Telephone Industries (ITI), situated in Bangalore, we shall show that the impulse for establishing a web of impersonal, well-codified standards governing the vexatious issue of occupational mobility came entirely from the rank and file and its representatives.

As Paul Osterman has rightly pointed out, "while it is true that internal labour markets can be imposed from above as part of an anti-labour strategy, they can also result from a struggle from below by workers for whom the system of job rights and regulation is a desired improvement". ${ }^{\text {IO }}$ To put it slightly differently, even assuming that bureaucratic forms of control contribute to organizing the workplace more efficiently and to obtaining the desired work behaviour from employees, neither of which is necessarily always true, employers are hardly the sole beneficiaries. Workers also derive appreciable advantages from routinized structures of labour control, given the constraints they place on managerial freedom, as various studies have illustrated. ${ }^{I I}$ By imposing definite curbs on the arbitrary whims and fancies of supervisors and foremen, these formalized policies contribute to further undermine their influence.

At the same time, we shall chart, so to speak, a middle ground by emphasizing the inherently ambivalent nature of internal labour markets. Far from typically operating as a zero-sum game to the sole advantage of one or the other protagonist, such a structure offers the potential for both employers and labour to advance their respective interests. If the management in ITI agreed, however reluctantly, to integrate seniority rights and promotions in a complex of bureaucratic rules, it was because it believed it could leverage

Io. Paul Osterman, "Introduction: The Nature and Importance of Internal Labor Markets", in idem (ed.), Internal Labor Markets (Cambridge, MA, I984), pp. I-22, I I. A similar argument is also put forward by Doeringer and Piore, Internal Labor Markets, pp. 57, 6I-63, I9I; and Eric Batstone et al., Consent and Efficiency: Labour Relations and Management Strategy in the State Enterprise (Oxford, 1984), pp. 290-293.

I I. See, inter alia, Lenard R. Berlanstein, Big Business and Industrial Conflict in Nineteenth Century France: A Social History of the Parisian Gas Company (Berkeley, CA, I991), pp. 3 I7-3 I 8; Bernard Elbaum, "The Making and Shaping of Job and Pay Structures in the Iron and Steel Industry", in Osterman, Internal Labor Markets, pp. 7 I-107; Jonathan Zeitlin, "From Labour History to Industrial Relations", Economic History Review, is (1987), pp. I 59-I84. 
these rules to achieve its long-sought after goal of flexible deployment of the workforce. Likewise, jointly-regulated employment practices symbolized for the union and its members a more transparent and just system of career progression. The mechanism of the internal labour market then fused together the divergent motivations and objectives of both parties in an unsteady equilibrium, and the cohabitation of these contrasting elements illustrated the contradictory character of this institution.

A further reflection of this contradiction, struggles by workers and their representatives to introduce internal labour markets, notwithstanding their undeniable mobilizing sweep, also paradoxically contained within them a divisive potential. This was because the new institutional framework not only threatened to suppress privileges enjoyed by specific groups of workers; it also tended to distribute its rewards in a somewhat skewed fashion, empowering many but not all. As this paper will demonstrate, these disparities invariably gave rise to sectional cleavages where, because of the conflicting nature of their demands, operatives from one production division were pitted against another, higher-skilled workers against lowerskilled ones, older workers against their younger colleagues, and, last but not the least, the union against an association defending the cause of "Untouchable" workers on the grounds that the newly instituted career ladders discriminated against them. Demands raised in favour of seniority entitlements and job advancement then are just as capable of instigating a concerted surge of labour unity as of undermining this unity, given the organizational stratification characteristic of the factory space. Nor does such duality seem to be particular either to the firm under review here or to the Indian context. Other authors have remarked too on the profound gender, racial, and generational biases at industrial workplaces that the establishment of seniority rights sanctified, and how this impeded the formation of a solidary movement. ${ }^{\mathrm{I2}}$

Research focusing on the functioning of internal labour markets in India is conspicuous by its absence. Existing historical sources shed no light on the growth of this institution, or the pace and extent of its diffusion across the industrial spectrum. But its emergence as well as subsequent development appears to have been a phenomenon essentially circumscribed to the public sector. One could speculate that because of the principle of joint regulation or "representative bureaucracy", the

I 2. See, inter alia, Carl Gersuny and Gladis Kaufman, "Seniority and the Moral Economy of US Automobile Workers, I934-46", Journal of Social History, I8 (1985), pp. 463-75; Michel Crozier, Le phénomène bureaucratique. Essai sur les tendances bureaucratiques des systèmes d'organisation modernes et sur leurs relations en France avec le système social et culturel (Paris, I963), pp. 8I-84; David Montgomery and Richard Schatz, "Facing Layoffs", in D. Montgomery, Workers Control in America: Studies in the History of Work, Technology and Labor Struggles (Cambridge, 1984), pp. I39-I 52. 
foundational element anchoring industrial relations in state-owned firms, where managements coopted the unions as subordinate partners in the task of administering practically all matters connected with the interests of the workforce, structural and ideological determinants favoured the emergence of internal labour markets in these entities to a far greater extent than in the private sector. ${ }^{13}$ Inversely, the weak representative base of trade unions in Indian private companies meant they were by and large not in a position to fight for formal career structures here.

The fact that the Indian public sector evolved as the central loci of such regulated processes also seems to have owed essentially to the results of bilateral contractual discussions featuring individual managements and unions. There are no signs of purposive policy interventions by the state. Prompt in snowing managements under an avalanche of directives and guidelines of all manner, the Bureau of Public Enterprises, the regulatory organ set up by the Indian government in the late I960s to monitor the functioning of state-controlled companies, maintained a stubborn silence on the issue of improving workers' wellbeing through seniority provisions and regular advancement opportunities. Nor were initiatives forthcoming from other official bodies.

In the existing scientific literature, internal labour markets are placed, implicitly or explicitly, in a diagonal relation with external labour markets. Through a cause-effect correspondence, corporate strategies are seen more or less as being patterned by and responding to conditions outside its boundaries. ${ }^{14}$ Contrary to the received view, as far as ITI was concerned, external institutional dynamics cannot be said to have impinged on its decision to adopt bureaucratic career structures. It operated in an overstocked job market where employment security alone mattered. So at no point of time did it experience a shortage of semiskilled hands. At the same time, competitive forces had little role to play in determining personnel policies, embedded as the company was in a totally protected and predictable business environment. A monopoly player until the mid-I980s, insulated even from the threat of exports, it was also assured of uninterrupted demand for its equipment as its parent authority and sole customer, the Post and Telegraphs Department, struggled to wipe out the mounting waiting list for fresh telephone connections. ${ }^{\text {Is }}$

Indeed, one could argue that the objective compulsions weighing upon the company to secure employee loyalty through the creation of internal

I3. The term is borrowed from Alvin Gouldner, Patterns of Industrial Bureaucracy: A Case Study of Modern Factory Administration (New York, 1964), p. 24.

I4. Doeringer and Piore, Internal Labor Markets, p. 3.

I5. In 1975, the registered waiting list for new connections stood at 637,000 lines, but these figures do not indicate the full potential demand for basic telephone services; Indian Telecommunication Statistics (New Delhi, 1985), p. 4. 
job systems, especially one as "closed" as the configuration it put in to place where workers were hired almost exclusively at the lowest entry point and where all jobs were filled from within through transfers or upgrading, were quite minimal. ${ }^{16}$ What constrained it to embark on this road was rank-and-file militancy.

It is also worth specifying that once workers succeed in obtaining permanent employment within a large "organized sector" firm like ITI, they are hardly disposed to compare their positions with the vast armies situated outside this "citadel of security and relative prosperity" ${ }^{17}$ If and when comparisons did come in to play and assume pertinence in orchestrating demands, they did so only with respect to entitlements granted by other public sector corporations and not private sector ones.

\section{WORKERS AND UNION DENOUNCE COMPANY RULES AS DISCRIMINATORY}

Founded in I948, a couple of decades later ITI already counted I 3,200 workers (essentially male) on its rolls, distributed across three product divisions, at its flagship Bangalore factory. Two of the divisions specialized in the fabrication of Strowger ${ }^{18}$ and crossbar electro-mechanical exchanges, while the third turned out transmission equipment. Right from the time of its inception, a single union represented the interests of the totality of the workforce. Consistent with the broader trend of plant-level unionism prevalent in the more modern and capital-intensive sectors of industry in Bangalore, the rank and file had also declined to seek affiliation with a national politically aligned federation in order to preserve organizational unity. This credo of independence would be further strengthened by the subsequent development of a culture of internal leadership.

A brief examination of the social attributes of the workforce highlights its strong local colouring. From a company document dated May I 970 we learn that 72 per cent of all non-officers originated from Karnataka, the southern Indian state housing the plant. ${ }^{19}$ This finding is confirmed by the results of

I6. Doeringer and Piore refer to a "closed type" of internal labour market; Internal Labor Markets, p. 45 .

17. Mark Holmström, South Indian Factory Workers: Their life and their World (Cambridge, 1976), p. I37. See also by the same author, Industry and Inequality: The Social Anthropology of Indian Labour (Cambridge, I984), pp. 5-7, 3I 2-3 I4.

I8. Patented by Almon Strowger in the US in May i891, the Strowger electro-mechanical switch marked the birth of automatic telephonic switching. Known also by its generic name of the "step-by-step" system, the switch responded to pulses emitted by the rotary telephone dial. Robust, simple to operate, of proven reliability, and relatively inexpensive to manufacture, the exceptional longevity of the Strowger technology can be measured from the fact that it remained operational in certain countries for over fifty years.

19. Note to ITI Board of Directors, I I sth Meeting, Item No. B7, 8 May 1970. 


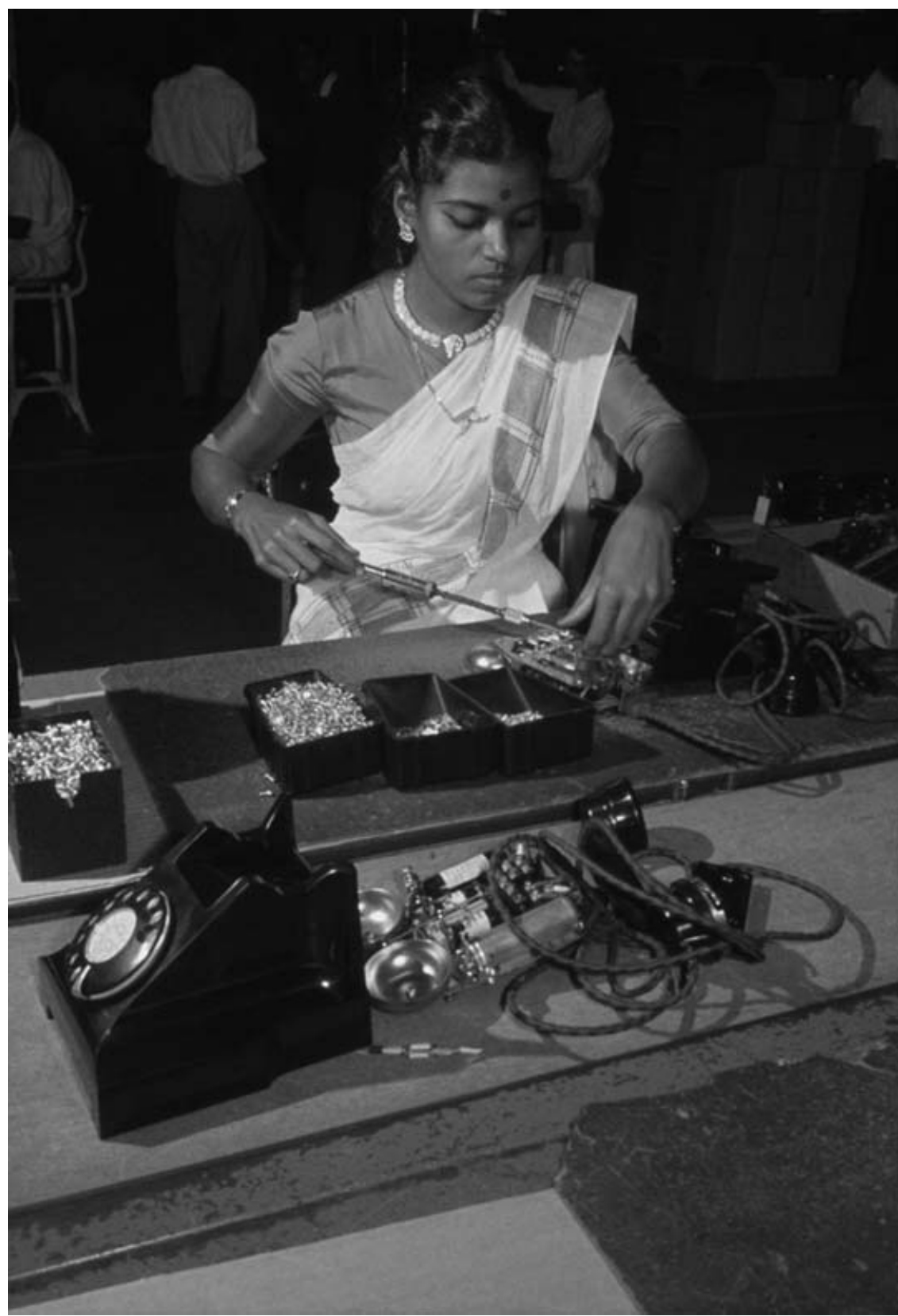

Figure I. This illustration meshes perfectly with the conventional image of the telecommunications equipment industry employing a primarily female workforce, given the large number of nimblefinger and sharp-vision jobs to be performed. Belying this stereotype, in state-owned Indian Telephone Industries men, and not women, made up the dominant group throughout the shopfloor. Photo by John Scofield/National Geographic/Getty Images. Used with permission. 
an intergenerational multivariate statistical survey which we undertook. The survey, which covers a population of I, I 29 employees hired by ITI over a span of fifty years (1948-1998), shows that three out of four employees came from within Karnataka for the period as a whole. Even the remaining quarter of the sample whose birthplaces were located outside Karnataka did not have to travel from very far afield. They belonged in the main to the three neighbouring southern states of Tamil Nadu, Andhra, and Kerala. ${ }^{20}$ So whatever interstate migration that occurred to tap job openings in ITI was essentially short-distance in character.

Information on the caste composition of the workforce is restricted exclusively to "Untouchable" employees. ${ }^{21}$ Even here the records are quite patchy, with quantitative data being available only from the midI 960 s onwards. "Untouchables" accounted for I4. I per cent of the factory strength in 1966. This figure increased progressively to 23.3 per cent by 1990 , in the wake of the job-reservation programme introduced by the Indian government in favour of these historically deprived groups. ${ }^{22}$ But notwithstanding this numerical growth, "Untouchable" employees remained disproportionately concentrated at the lowest strata of the occupational hierarchy. The most disadvantaged sections in the factory on all counts, they carried over intact into the realm of work all the enduring deprivations and disabilities afflicting them in the broader societal context. A reflection of their rudimentary educational and technical qualifications, they were given practically all the dirtiest jobs to perform. ${ }^{23}$ Inversely, in auxiliary occupations such as production planning, storekeeping, and draughtsmanship they did not even make up 4 per cent of our total survey population.

Since establishing steady advancement paths had ranked at the bottom of the ITI management's priorities, opportunities for moving up the job ladder were limited and depended on the unrestricted discretion of foremen and shop superintendents. With a labour force composed of young workers, and turnover rates insignificant, mobility hinged essentially on the creation of new posts, which in turn was contingent on increased production volumes.

20. While the totality of the findings of the sample survey can be found in my doctoral dissertation, parts of the results of have been published in my paper, "A Sociological Profile of a Public Sector Workforce”, Economic E Political Weekly, 5 I (2007), pp. 37-47.

2I. That no data is available for the other castes is fully in consonance with official state policy orientations, which for ideological, political, and practical reasons, do not recognize and thus do not statistically enumerate in the national census, caste groupings, barring the "Untouchables", subjects of a comprehensive compensatory discrimination programme.

22. Figures provided by ITI Personnel Department.

23. For instance, at no point in time between 1966 and 1990 did the number of sweepers who belonged to the "Untouchable" communities drop below 77 per cent. In some years the figure even reached soo per cent; ibid. 
At the same time, an extremely constricting classificatory grid disposed workers in the two biggest divisions, Strowger and transmission, in terms of their trade and grade-wise seniority on a shop or departmental basis. This gave rise to narrow lines of progression, where, for instance, a category 6 driller or turner in the Strowger relay machine shop, or wireman in the relay assembly shop, could only expect to move to a category 5 job in the relay machine or the relay assembly shop, and not in any other Strowger department, let alone another division such as transmission or crossbar. "Supervisors were not encouraging movement from one shop to another [...]. If we lost one worker, we would not get a replacement. So workers would grow in the same shop or hangar." 24

The scope of lines of progression or mobility clusters, observe Doeringer and Piore, typically oppose the interests of management and the labour force. ${ }^{25}$ While the latter favour broad lines of progression with extensive geographical and occupational coverage, so as to further advancement opportunities, employers seek instead to restrict mobility clusters to individual departments. The biggest drawback associated with the seniority system in ITI was that it discriminated against long-serving workers. Despite performing the same kind of job, senior workers in shops characterized by comparatively low levels of mobility sometimes lagged behind their juniors who worked in shops offering more promising promotion prospects. Not surprisingly, this kept alive a permanent source of tension inside the plant.

Departmental promotion committees, consisting of the Personnel Manager, the Administration Officer, and the departmental head concerned, and blessed with considerable powers, conducted the screening process. While according due weight to seniority, they also emphasized merit and suitability as operative criteria, the interpretation of which rested upon the committee members' evaluation of a worker's disciplinary record and other reports. Although the union waged a constant fight to prioritize length of service, the company believed that excluding the other two factors would undercut efficiency by elevating individuals regardless of their ability.

Not that the departmental committees distinguished themselves as paragons of allocative efficiency. Exploiting their latitude to reward undeserving candidates more often than they might have wished to recognize, some of the committee's decisions only served to prove that the rubbery gauge of "ability" as a measure of fitness could mean anything that management wanted it to mean. Promoted twice in consecutive years, Ramaswamy, an accounting clerk, got a fresh promotion the very

24. Interview, M.V. Srinivasa Rao, February-March 1999.

25. Doeringer and Piore, Internal Labor Markets, p. 59. 
same year his superiors issued him with a couple of warnings for negligent work. ${ }^{26}$ The case of Achar furnished an even more damning indictment of the twin norms of merit and suitability championed by the company. A clerk in the shipping department, he was reprimanded on no less than ten different occasions for various offences, suspended for one day, and saw his increment postponed for several months. Yet none of this deterred the departmental committee from appointing him to higher ranking posts twice in the span of a decade. ${ }^{27}$

Small wonder then that the entire selection process came in for scathing criticism from union and workers alike, who accused foremen especially of playing favourites. Over 40 per cent of ITI workers surveyed in one study harboured the conviction that "no honest man could make progress in the factory". ${ }^{28}$ Asked to rank the most important criteria in determining mobility, they first cited seniority, followed by favouritism, better training, and, lastly, merit. Voicing a widespread sentiment, one operative said, "I am a good worker, but the one who used to get promotion is the worker who sucks up to the management." ${ }^{29}$ A retired shop boss acknowledged that, "there were some cases of partiality in promoting workers. Some officers were getting personal and domestic work done by workers, taking bribes and gifts from them in the form of loans. Workers understood that these loans would never be repaid." ${ }^{\circ}$

Discrimination was also sometimes seen as wearing the garb of caste. After noting that little distinguished the quality of his workmanship from that of his colleagues, a chargehand in the rack-wiring department openly accused the management of turning down his repeated requests for promotion because he belonged to an "Untouchable" caste. ${ }^{3 \mathrm{I}}$ According to another worker, "when departmental promotion committees existed, caste feelings came in the way of workers getting promotion. Brahmins were getting priority because lots of officers were Brahmins. Anti-'Untouchable' feelings were very strong at one time." ${ }^{2}$ Mobility data drawn from our sample survey too reveals the far higher levels of discrimination faced by "Untouchables". While one out of three caste Hindus in our sample got zero or just one promotion in a span of ten years, in the case of "Untouchable" employees this figure totalled 45 per cent. ${ }^{33}$

\footnotetext{
26. Personnel File No. 137.

27. Personnel File No. 597.

28. P.P. Arya, Labour Management Relations in Public Sector Undertakings (Delhi, 1982),

pp. $27-28$.

29. Interview, Vinayagam, 22 November 200I.

30. Interview, S. Mukherjee, 8 February 1999.

3I. Letter from David Chandra Paul to ITI General Manager, 24 August 1960.

32. Interview, Govindaraju, 27 November $200 \mathrm{I}$.

33. Subramanian, "Sociological Profile of a Public Sector Workforce," p. 45.
} 
Workers and their representatives highlighted other shortcomings as well in the promotion policies. According to the company, although the wage scales for each of the seven categories across which the totality of the labour force was distributed were designed to cover a maximum tenure of ten years before a worker arrived at the end of the scale, most people progressed to the next level well before then. During the first half of the ig6os, shopfloor operatives obtained, on average, a promotion at an interval of four years and seven months, though the delay for clerical staff extended to six years, and for other groups such as drivers to six years and three months. ${ }^{34}$

Nevertheless, there were several instances of workers stagnating in each category; having attained the upper limit of the wage scale, they found all avenues for upward advancement blocked. Unskilled groups such as helpers, labourers, and sweepers, or those lacking formally certified qualifications, in particular, were trapped in these dead-end jobs. To give just one instance, Muthiah, who joined as a sweeper in 1949, earned his first promotion sixteen years later. ${ }^{35}$ The management, though, described his condition as "inevitable" since higher-category jobs could not be created artificially to accommodate employees. ${ }^{36}$ As a palliative measure, shop heads occasionally recommended workers for special increments. But while permitting worthy candidates to be rewarded, such discretionary incentives, symbolic markers of managerial authority, also inevitably lent themselves to abuse.

Complaints from machine tenders about facing discrimination vis-à-vis their counterparts in assembly shops could also be frequently heard. Because they were responsible for bringing out the final product and hence were strategically better positioned to disrupt delivery schedules, assembly hands could effectively count on more promising career prospects. So even as the factory kept expanding numerically, the lack of occupational mobility grew even more pronounced. Between October I 966 and September 1969, barely 3 per cent of the total workforce at the Bangalore plant succeeded in qualifying for promotion, although the management deemed this figure to be "satisfactory". ${ }^{37}$ As a result, workers were condemned to even longer periods of waiting: if it had taken production operatives under five years in 1964 to climb from one category to the next, in 1969 it took on average seven years and three months to climb from category 6 to 5 , and six years from category 5 to $4 .{ }^{38}$ Attempts by the union to try and revise the company's promotion policies by fighting it in the labour courts also proved abortive.

34. Minutes of management-union meeting, 7 July 1964.

35. Personnel File No. 478 .

36. Minutes of management-union meeting, 3 September 1965.

37. Minutes of management-union meeting, I9 January 1970.

38. Ibid. 


\section{WORKERS SEEK REDRESS THROUGH PETITIONS}

Because the question of an orderly career progression is intimately entwined with notions of self-adequacy, personal legitimacy, and justice, the denial of promotion opportunities, by contesting workers' ability, did not fail to provoke cracks in what Richard Sennett has called "the badge of individual worth". ${ }^{39}$ As one employee declared after having been superseded by a junior colleague, "such incident pulls me down and make me sick due to mental agony [sic]". ${ }^{\circ}$ Another worker who received a warning for "unruly behaviour" after coming to the factory in an inebriated state, much to the surprise of his superiors who had never seen him exhibit such "strange behaviour" before, spoke of his disappointment at not having been promoted. ${ }^{4 \mathrm{I}}$ Still another submitted his resignation in a fit of anger, before withdrawing it. All these and other employees effectively understood their careers in terms of what Everett Hughes has defined as a "moving perspective in which the person sees his life as a whole and interprets the meaning of his various attributes, actions and the things which happen to him". ${ }^{2}$

But workers did not bow passively to these perceived injustices, symptomatic in their eyes of managerial arbitrariness and partiality. In addition to the weapon of union pressure, they also deployed individual strategies to articulate their grievances and seek redress. Some sought the intercession of influential outside patrons such as politicians or government officials who wrote to the company to endorse the requests of their clients, "a genuine hard worker but unfortunately [...] he is allowed to be superseded [sic]". ${ }^{43}$ Others threatened to take the exit route and regularly applied for jobs elsewhere. But in their quest for justice the technique most widely utilized by far by ordinary workers was the petition.

We have been able to assemble a small corpus of these documents. By recording first-hand the grievances and argumentative codes employed by workers to vindicate their claims urging promotion, these sources provide us with precious insights into their feelings and aspirations. ${ }^{44}$

39. Richard Sennett, The Hidden Injuries of Class (New York, 1972), pp. 62, I53-155.

40. Personnel File No. i 869 . Citation as in original.

4I. Personnel File No. 4838 .

42. Everett Hughes, "Institutional Office and the Person", in idem, The Sociological Eye: Selected Papers (Chicago, IL, I97I), p. I37.

43. Letter i 8 June i955.

44. On the importance of petitions as a medium for historians to reconstitute the lives of ordinary people, see, inter alia, Lex Heerma Van Voss, "Introduction: Petitions in Social History", International Review of Social History (Supplement), 46 (2001), pp. I-10; David Zaret, "Petitions and the 'Invention' of Public Opinion in the English Revolution", American Journal of Sociology, Iо I (1996), pp. I497-I 555 . 
Indeed, supplications constitute the sole formal archival traces directly left by ITI workers - traces from where their voices emerge undistorted and unmediated by the management and the union, even if we allow for the formulaic quality of the appeals, and the fact that their veritable authors may sometimes have been friends, colleagues, or professional scribes, equipped with the requisite expressive conventions to plead the petitioner's cause.

Of the thirty petitions that make up our sample, thirteen were submitted by auxiliary workers (storekeepers, planners, inspectors, etc.), seven each by clerical staff and production workers, and three by service personnel (drivers, sweepers, etc.). ${ }^{45}$ Barring eight of the petitioners, all the others possessed fairly high levels of technical skill or educational qualifications. An analysis of the form and content of these texts uncovers a number of common characteristics. Written in English and typed, both details implying that certain employees probably enlisted the services of more literate persons to help them frame their representations, these varied in length from one to three pages, though the majority did not extend beyond a page. In line with factory procedures, workers appealed in most cases directly to the highest authority in the plant, the managing director or the general manager.

Well aware that "posing as humble supplicants (was) a necessary aspect of petitioning", the idiom of deference pervaded their requests. ${ }^{46}$ But synonymous as deference may have been of the weakness of the petitioner's position, it could not conceal their resentment; the aggrieved tone saturating the texts leaves no one in doubt as to whom workers blamed for their status woes. While leaving unchallenged the management's right to decide labour mobility, the supplicants did not hesitate to challenge the soundness of its decisions.

In terms of their construction, the petitions adhered by and large to an identical narrative format where the workers telling of their "work histories" unfolded in three successive moments or acts. The first moment foregrounded what could be called the rhetoric of demonstration. Here petitioners sought to demonstrate their ability and value to the company, thereby implicitly contrasting their loyalty with the management's disloyalty, in order to justify, and to make self-evident their demand for promotion. The repertory of arguments each individual developed for this purpose illuminated the plurality of interpretations workers attached to the significance of their work.

45. There is no way of finding out whether the petitioners were members of the union or not. Participation in the union consistently topped the 95 per cent mark only from the early r 970 s onwards when the ITI management agreed to implement a system of "check-off", deducting subscription dues directly from workers' pay packets.

46. Potukuchi Swarnalatha, "Revolt, Testimony, Petition: Artisanal Protests in Colonial India", International Review of Social History Supplement, 46 (200I), pp. I07-I 29, I I 4. 
They highlighted their faithfulness to the company: "I am aged 37 years and fifty per cent of my age has already been devoted in rendering my service to ITI", (Dhanraj, attendant); "I have put up a total service of 22 years in our esteemed organisation without any bad remarks", (Zacharias, chargehand). They stressed their diligence: "I have neither availed a single day's leave on loss of pay or punched my card late on any occasion during my ten years service in this factory", (Nair, machine tender); "I have not only allowed the innumerable mental worries not to disturb my quality of work, but also I have tried my level best to put in the maximum zeal possible", (Ranganathan, planner).

They drew attention to their skill and efficiency: "I know my work [...] I know the nook and corner of factory, and how to keep such places tidy and clean $[\ldots]$ what to do during the time of heavy rains, etc.", (Abbiah, sweeper); "the recent celebrations for bringing out the roooth Rack must give you an insight into the amount of work put in by me all through and the amount of technical knowledge derived thereby", (Subbiah, planner). They emphasized the importance of valorizing practical experience over formal qualifications: "kindly give due consideration to the qualities required for day to day production than for any such qualifications through certificates which may not very help a progressive industry like ours", (Masilamani, inspector).

They pointed to the heavy responsibilities shouldered by them: "In this kind of work [...] important and far reaching decisions have to be taken on the spur of the moment [...]. This requires my unceasing vigilance and alertness at all times [...]", (Dharmalingam, senior shop clerk); "It may not be out of the way if I mention that I have actually become very indispensable in the big, huge, highly transacted telephone stores since the present senior Store Keeper is quite new to his job", (Gopal, storekeeper). They referred to their willingness to assume additional tasks: "From March 1952, I was acting as a Supervisor in the Joining-up Section. After a few months I was asked to look after Bank-Multiple Section too. From that time onwards, I was looking after both the sections without any promotion or increments", (Chandra Paul, chargehand).

They underlined their contributions and achievements: "I played my part in successfully bringing out in an attractive manner the booklet entitled Six Years of Progress. Considerable ingenuity had to be employed in giving the final touches to this publication", (Vedavyasa Rao, senior clerk); "The production which was far below the schedule was brought up to schedule by me. Further [...] I have been awarded two awards for the suggestions made by me", (Ananthu, chargehand).

Petitioners supplemented these work-related topoi with one important extra-work argument to legitimize their claims for upward advancement. This centred on the financial hardships involved in supporting a large 
family on a small salary. In the words of Nagabhushan, a typist in the engineering department,

My present basic salary is Rs 95 per month [...]. My family consists of six souls and the monthly minimum maintenance comes to approximately Rs 200 . I leave this to your sweet discretion to see how much I am disabled every month even to meet the very essential needs of a growing family particularly in these hard days. ${ }^{47}$

Adds Papaiah, a semi-skilled worker: "As I am having a large family to support and I being the only earning member, I am finding it very hard to maintain my family in these hard days as the income I get by way of salary $[\ldots]$ is not at all sufficient to meet both ends." ${ }^{8}$

In addition to functioning as a testimonial to the individual capabilities of workers, the petitions then also conveyed an explicit reminder to the company of its obligations to sustain the material wellbeing of petitioners and their families. In sum, the principles of justification mobilized by workers in their contention with the management, if they were to some extent grounded in a domestic order of worth which focused on values such as loyalty to superordinates and reciprocal duties, drew their inspiration primarily from the same industrial order of worth upheld by the company, where the yardsticks of productivity and efficiency served to measure individual worth. ${ }^{49}$ It was because both workers and management belonged to the same "moral" world that the claims of the petitioners could appear as sensible and legitimate. ${ }^{50}$ The contention between the two sides did not correspond to a confrontation between two rival regimes of justification or generality, thus facilitating the possibility of arriving at a compromise.

\section{SENIORITY RIGHTS: “KEYSTONE OF WORKERS” MORAL ECONOMY"}

The second moment in the narrative process was informed by the rhetoric of denunciation. The act of denunciation actually encapsulated two forms of injustice. First, workers reproached the management for denying them promotion. In the majority of instances, grievances had to do with the marginalization of seniority claims because promotion rules often enabled

47. Letter to ITI Personnel Manager, I8 June i955.

48. Letter to ITI Works Manager, I August 1955.

49. Luc Boltanski and Laurent Thévenot, De la justification (Paris, I991), pp. 206-2 I6, 253-259.

50. Analysing complaints addressed by workers to the authorities in post-reform China, Thireau and Hua also underscore the discursive importance of elaborating a set of normative referents which, by appealing to common notions of equity and justice held by the powerful and the weak alike, place the former under a moral obligation to intervene in favour of the petitioners; Isabelle Thireau and Linshan Hua, "Le sens du juste en Chine. En quête d'un nouveau droit du travail", Annales HSS, 6 (200I), pp. I283-I3 I 2. 
junior workers to vault over the heads of more senior colleagues. The following lines exemplified the reactions of several petitioners: "I was anxiously waiting for my next promotion in the near future. But to my surprise I came to know that some of my juniors were promoted [...]. Even I can't dream of such a thing to be happened [sic]." ${ }^{\text {I }}$

Supplicants sometimes backed their complaints with detailed comparisons of career trajectories to prove that they had effectively been superseded by their juniors. Workers with poor disciplinary records but who had been promoted were singled out. Overall, the petitions bore witness to the attentiveness with which workers surveyed promotion movements across the factory - a task rendered relatively easy by the classificatory system adopted by the company where all workers were identified by a serial number, the higher the number the more junior the worker and vice versa. Paradoxically, even as the arbitrariness of the management in giving promotions turned the factory into an arena of competing claims, the bureaucratization inherent in all industrial organizations by creating what could be called "enumerated communities" greatly facilitated the process whereby workers could stake out their claims. $^{52}$

At the same time, petitioners continued to pitch their demands exclusively in the language of seniority, the "keystone of their moral economy" as it were, even though the management religiously informed disappointed candidates that other criteria also determined promotion decisions. ${ }^{53}$ From the point of view of workers, instituting seniority provisions to regulate occupational mobility not only provided a bulwark against arbitrary management control; it represented a moral claim for preference over newer entrants by those who had devoted long years of their lives to the company. In an occupational context defined by scarce opportunities for progression and which pitted one group of workers against another in the fight for these opportunities, no other principle could appear more equitable to them than this one. ${ }^{54}$

The second form of injustice petitioners denounced related to the management's failure to respect its engagements. Quite a few workers

51. Letter from Palainiswamy to ITI Managing Director, I 3 October 1963.

52. The term, "enumerated communities", is borrowed from Sudipta Kaviraj. He has, however, used it in the context of a modern nation-state which, deploying various techniques of objectification, creates an enumerated community; "The Imaginary Institutions of India", in P. Chatterjee and G. Pandey (eds), Subaltern Studies VII, (Delhi, I992), pp. I-39, 26.

53. Gersuny and Kaufman, "Seniority and the Moral Economy of US Automobile Workers", p. 464 .

54. No scientific answer exists as to whether seniority rights are socially desirable or undesirable. But depending on the perspective, privileging length of tenure has both costs and benefits; Richard Freeman and James Medoff, What do Unions Do? (New York, I984), pp. Is, I33-I 35 . 
spoke of having received oral assurances of promotion from their superiors if they performed satisfactorily. But while they had laboured hard to keep their part of the bargain, company officials had not done so and therefore let them down. One act of injustice - unrewarded effort - was thus compounded by another - the betrayal of a promise. Pointing out that he had "joined the factory on the assurance that I will be promoted if found efficient in about six months", Gangaraju, an inspector in the test set department complained bitterly of having to wait "four long years" before being promoted; even then he was still earning less than his previous employer used to pay him. ${ }^{55}$ Equally resentful, Sundar, an inspector in the relay adjustment department wrote that he had,

[...] been promised orally by the Works Manager before the SSS (senior shop superintendent) and some of my co-workers that I would be posted to a place where cat. (category) 4 was done and if I were to pick up that job, I would be considered for promotion to cat. $4 .^{56}$

But five years later management had still not fully honoured its "oral assurance".

The third and final moment in the narrative structuring of the petitions was underpinned by the rhetoric of affect. Here, the injustice experienced by the petitioners found expression in the language of feeling and emotions. Here, we can hear workers voicing their hurt and anger, their disappointed hopes, the injuries inflicted upon their dignity by the denial of what they judged to be their due rights to mobility, expressing frustration at the lack of adequate rewards for their efforts and loyalty.

A clerical employee with a "fine record of loyal and efficient service" felt abased at having to request the management for promotion because "I never thought that I would have to fight out my case for recognition, as due recognition of services rendered by me should have automatically come off long ago from the righteous management of this reputed concern." 57 Prahlada Rao, a factory guide, complained that he had been "relegated to a very pathetic level" after twelve years of service, thus totally belying his expectations of "a fairly good career in ITI"..$^{8}$ Resentment against the management for refusing to provide sufficient positive incentives also surfaced in other petitions. Despite "spar(ing) no pains in putting my knowledge into my daily work", Muthe Gowda, a technical assistant in the production planning department claimed that "his progress in the Deptt. [department] has not been in relation to the

55. Letter to ITI Managing Director, I9 January 1955.

56. Ibid.

57. Letter from D. Dharmalingam to ITI Personnel Manager, 22 June 1955.

58. Letter to ITI Joint General Manager, I3 June 1964. 
important projects entrusted to me and their progress and expansion day by day". 59

All of this was bound to have exercised an adverse effect on the performance of workers. Indeed, so discouraged was one "diligent, sincere and enthusiastic" draughtsman by the fact that his promotion claims had been overlooked "in preference to those who had similar qualifications and less experience" than him, that he believed this "invidious distinction" was "bound to dampen the enthusiasm of an official like me entrusted with work of a responsible nature in an important department like Industrial Engineering". ${ }^{60}$

Other employees who possessed the requisite resources, such as sportsmen representing the company, threatened even more explicitly to withhold their services. Thus, a cricket player whose talents had propelled the company to distinction in local tournaments warned the management that he would quit ITI to join a rival public enterprise because his juniors had received promotion but not him. The threat did not go unheeded: the following year the employee advanced to a higher-category post. ${ }^{6 \text { I }}$ Such cases where workers commanded sufficient individual bargaining power to deliver an ultimatum and extract concessions from the management were, however, exceptional. For the overwhelming majority of petitioners, their best chance of obtaining their requests for promotion rested on showing the maximum on-stage deference. Besides, as "demands for a favour, or for the redressing of an injustice", the very nature of the petition itself excluded the usage of a belligerent tone. ${ }^{62}$

\section{UNION STRUGGLES TO IMPOSE RESTRAINT}

These demonstrations of humility, though, did not in any way connote passivity or submissiveness on the part of the workforce. Alongside such individual mechanisms as the petition, workers also resorted to more collective forms of protest to press their grievances. The first recorded traces of concerted action over the question of promotion opportunities date back to October 1965. The management complained that a small group of inspection staff in the Strowger switch-wiring shop had launched a go-slow. From fifty switches daily, they were now checking only thirty-odd switches, thereby affecting production both in the shop and in other departments. According to the union, these actions reflected

59. Letter to ITI General Manager, I 8 November 1956.

60. Letter from Ramaswamy to ITI General Manager, 22 January 1959. ITI workers cited "quicker promotions" as the measure most conducive to stimulating higher individual work effort; Arya, Labour Management Relations, p. 66.

6r. Letter to ITI General Manager, I 2 June 1957.

62. Heerma van Voss, "Petitions in Social History", p. I. 
the inspectors' unhappiness at the absence of established perspectives of career progression. ${ }^{63}$

Unrest once again spontaneously flared up in June I971, but on a much broader scale this time. Concentrated in the main Strowger division, the immediate cause of the trouble had to do with the management's hasty and imprudent decision to implement the recommendations of a job-evaluation committee in the crossbar and transmission divisions. The creation of the crossbar division in 1965 , coupled with changes in the nature of manufacturing processes for Strowger equipment, had led the management to institute a plant-wide job-evaluation scheme in the mid-1960s. Priority was given to the crossbar division, a new product line and where delays in conducting the evaluation had produced "a lot of dissatisfaction", since no promotions could be granted so long as the various occupations had not been "objectively" codified and distributed hierarchically. ${ }^{64}$

In January I97I, the committee submitted its report with respect to crossbar and suggested upgrading virtually all lower-category jobs. In the case of Strowger, because of the "complexity and the large number of jobs involved", the committee still remained many months away from finishing its task. ${ }^{65}$ But instead of waiting for the entire evaluation process to be over, and influenced, no doubt, by the status of crossbar as the showcase of the company, the management announced at the end of May I97I promotions for as many as 460 crossbar operatives and for 300 transmission division operatives. ${ }^{66}$ Predictably enough, the news unleashed a surge of anger amongst the Strowger workers.

Demanding that their loyalty to ITI be rewarded by the same treatment extended to crossbar and transmission workers, around 3,700 Strowger machine and assembly hands now went on a two-day-long wildcat strike in early June. ${ }^{67}$ Only after the management promised to ensure the rapid completion of the job-evaluation programme did the union representatives succeed in restoring order. Still, sporadic work stoppages continued to interrupt the flow of production throughout the month in the relay, switch, and telephone machine and assembly shops, notwithstanding warnings from the company that such illegal work practices would invite punishment. ${ }^{68}$ Nor did partially meeting a longstanding demand of the union and the workers to modify the seniority rules, with a view to better facilitating the movement of personnel from one shop or department to the other, pave the way for a return to normality.

63. Minutes of management-union meeting, is October 1965.

64. Note on Promotion Procedure and Present Position, 7 July 1972.

65. Ibid.

66. Reply to Ministry of Labour Questionnaire, 1972.

67. Ibid; minutes of management-union meeting 2 June 197 I.

68. Position regarding Labour Situation at ITI Bangalore, n.d. [1972]. 
More worryingly for company officials, the agitation also began progressively spreading to other areas of the factory. Already in March I972, nearly 600 clerical staff "came out of their offices $[\ldots]$ and were standing silently in the veranda" to protest against the delays in completing job evaluation of non-production activities. ${ }^{69}$ The walkout ended quite quickly after the union representatives intervened and persuaded employees to return to their work spots. But the fact that the union was "neither a party nor supported this demonstration", far from reassuring the management, was, on the contrary, a disturbing indication that the former did not fully control the situation. ${ }^{70}$

This was further borne out by another event. Towards the end of April, between 300 and 400 Strowger operatives assembled near the main canteen in anticipation of a meeting with top union officials. Irked by their failure to appear after a while, the demonstrators then converged upon the administration gate, or "justice gate" in worker parlance, which separated the factory premises from the administrative offices, and raised slogans crying "We Want Justice", "We Want Fernandes", the union president. When Fernandes came out, accompanied by other delegates, workers reiterated their demand for equal opportunities with crossbar and also wanted further changes to be made in the seniority rules since the fundamental question of the protection of long-service workers' rights remained unresolved.

Immediately after this incident, the head of the personnel department wrote to the union to air the management's concern over the difficulties experienced by the union leadership in imposing its authority over its increasingly recalcitrant members. Stating that instances of "large number of workers leaving their places of work and collecting around some Union Office Bearer or the other to demonstrate or voice their protest" were growing in frequency, he expressed surprise that "such abandonment of work, demonstrations, etc., have been happening [...] in the absence of a specific $[\ldots]$ and important dispute between the Union and Management”. After pointing out that the ITI chairman had personally discussed all these problems with the top union leaders, the letter ended by brandishing the threat of a lock-out in case the various acts of "mass indiscipline" remained unchecked. $^{71}$

A few days later at a meeting between the two sides, the management again underscored the role of the union in preventing "indiscipline [...] and loss of production". ${ }^{72}$ None of these admonitions delivered the anticipated results. From an internal note dated so May, we learn that in

69. Ibid.

70. Ministry of Labour Questionnaire.

7I. Letter from Personnel Manager, ITI Bangalore to ITI Employees Union, 29 April 1972.

72. Minutes of management-union meeting, Iо May 1972. 
the key automatic machine shop which fed the entire plant, setters and operatives who previously attended to five machines were now refusing to attend to more than four machines, and that too only if they were aligned in a row; in the Strowger switch-adjustment shop, operators were only willing to adjust the switches and not repair them, despite being required to do both jobs and despite being promoted; similarly in the Strowger plating shop, recently promoted workers were executing only a portion of their tasks; in the coil winding department, though a number of lower-category jobs had been upgraded, efficiency levels had dropped from $\mathrm{I} 20$ to 80 per cent. $^{73}$

Another note dated I 2 May revealed that the unrest had enveloped a number of crossbar shops as well. For reasons of flexibility as well as labour control, a practice commonly followed by shop officials consisted of assigning a higher-category job to lower-category workers, on the understanding that they would be promoted within a year or so if they accepted to do the job in the interval and met the required targets. Now, crossbar operatives in several assembly shops plus the testing department refused to continue performing higher-category work after learning that their promotions would be delayed.

Ironically, it was not the management but the union which was responsible for the delay. Pointing out that it was on the verge of finalizing its proposals to amend the existing seniority rules and introduce a system common to the whole factory, the union leadership had requested the company temporarily to withhold all promotion decisions in order to "avoid the discontent among some sections of workers from assuming larger proportions". ${ }^{74}$ When crossbar line managers asked the shop delegate to communicate this information to the operatives and instruct them not to slow down work, the delegate "expressed his inability to speak to them and advised us to speak to the (union) Secretary or Vice President".75

Machine tenders in the crossbar power press and drilling sections were suspected of planning to imitate the example of their assembly colleagues as well, raising fears of a breakdown in the supply of vital piece parts to assembly. To add to company officials' woes, they could also not enforce disciplinary sanctions against the workers for refusing to carry out highercategory tasks as these were "clearly beyond the purview of their legitimate work" ${ }^{76}$ Soon afterwards, overtime work ground to a halt as attendance had dropped by Io to $\mathrm{I} 2$ per cent, thus further hampering production. Output levels for the plant as a whole were not even expected to cross those recorded the previous year, let alone meet the target fixed for 1972-1973. 
In early June, angered that they had still not obtained their promotions, between 100 and I 50 crossbar workers marched to the administration building where they staged a sit-down demonstration. Chanting slogans attacking both the management and the union, they dispersed after about thirty minutes. ${ }^{77}$ The following month it was the turn of Strowger workers in the selector shop to down tools for almost three hours, demanding the same promotion benefits as those granted to crossbar workers. ${ }^{78}$ A few days later, an even longer work stoppage occurred, lasting six hours, involving employees from the plant mechanical department in all divisions. The department head reported that all the workers had gathered outside the main hangar to discuss their "grievances regarding promotion and seniority"..$^{79}$

Subsequently, shop officials suspended nine mechanics on charges of refusal to work and encouraging their colleagues to stop working. The entire department then promptly walked out, causing disruptions to "essential services like compressors and boilers" ${ }^{80}$ To ensure that these could not be operated, switch fuses were removed and thrown away, and supervisory staff forcibly prevented from attending to the equipment. Interestingly, an official document claims that the mechanics had expressed their hostility to the principle of a combined factory seniority being debated by the union; they preferred the prevailing division-wise configuration, viewed as far more conducive to their career advancement chances.

From the foregoing account, the wholly spontaneous character of the agitation is self-evident, the union intervening at various moments only in its disciplinary or social-control capacity to try and restore order. Acting on their own initiative from start to finish, workers' anger in certain instances appeared to be directed as much at the union leadership as at the management, their protests being designed to keep up the pressure on both parties. Aware that their particular interests often stood at odds with those entertained by other groups, thus placing the union in a delicate position, each group of workers pinned its faith on its own strength, seeing direct action as the most effective means of making its voice heard.

At the same time, the agitation proved to be a protracted affair, dragging on for almost a year, even though the tremors that shook the plant with the greatest frequency, if not intensity, were concentrated during a six-month period stretching from March to August 1972. But, paradoxically, the actual demonstrations, the work stoppages, the walkouts, and so forth rarely lasted for very long; whether these forms of

77. Ministry of Labour Questionnaire.

78. Ibid.

79. PD files, 9 August 1972.

80. PD files, I I August 1972. 
protest could not be sustained beyond a short period because of workers' inability or reluctance to organize themselves more effectively is a moot question.

That the confrontation persisted for several months can be explained by the highly charged nature of the underlying issue of contention. Occupational mobility not only fused together material and symbolic rewards, money and status, in one indissoluble whole. It not only constituted the principal arena where questions of justice and equity emerged to the fore with sharp focus, given the importance accorded by workers to the question of seniority rights - the conviction that career progression stood in direct proportional relation to service tenure occupying a central place in their worldview. In the context of industrial work, where, pace Sennett, the injuries of class were not always hidden, it also played a fundamental role in validating and reinforcing the selfimage of workers by operating as a tangible marker of recognition of their individual abilities and contributions to the enterprise. ${ }^{8 \mathrm{I}}$ The struggle for improved promotion opportunities was thus also undeniably a struggle for dignity and respect, one that workers waged in order to carve out a meaningful place for themselves in a hierarchical factory community.

Yet, notwithstanding its exceptional duration and its impact on production, the conflict remained small-scale and localized in form. Of the three production divisions, one, transmission, experienced no disturbances whatsoever. Even in the other two divisions, going by the official documents, participation in collective action tended to be rather restricted. In Strowger, the epicentre of the agitation, barring the wildcat strike at the start, the majority of workers appear to have stayed quiescent. This was also true in the case of crossbar, where the protests to boot did not spread beyond the walls of the assembly shops to suck in the machine shops.

More significantly, as we have seen, workers in the two divisions were not bound by a common set of demands. Whereas delays in granting promotions occupied centre stage in crossbar, Strowger workers wanted the same promotion entitlements as those bestowed on crossbar personnel. It was this disjunction in the nature of the demands which essentially accounted for the fragmented, uncoordinated, and sporadic character of the agitation. The succession of local disputes that punctually flared up never threatened to have a snowball effect and coalesce into a factory-wide strike. To put it slightly differently, instead of a battle

8I. As Sennett again pertinently observes, rewards for blue-collar workers were earned collectively, through contractual bargaining which distinguished categories and not individuals, whereas white-collar rewards flowed from the recognition of individual achievements; Sennett, Hidden Injuries of Class, pp. 35-36. 
of full-blown proportions, organized and directed from the top, which united the mass of workers in a common cause and simultaneously erupted on all fronts, the company witnessed a series of individualized, short-lived, spatially circumscribed skirmishes "led" from below and staggered in time.

\section{NEW SENIORITY RULES INSTITUTED}

What ultimately brought the wave of protests to a close was an agreement signed by the management and the union in August 1972 enshrining a new set of seniority norms to govern promotion decisions. The principle of divisional seniority adopted earlier in most production areas now gave way to a tradebased segmentation encompassing the factory in its entirety. All operatives were segregated, first vertically in terms of their designated trades, and then horizontally in terms of their category within each trade. This highly bureaucratic exercise entailed identifying all the different machine and assembly trades available within the factory (forty-five and fifty-seven respectively), after which trades sharing fairly similar levels of skill and responsibility had to be consolidated into a single group. So welders formed one group, wiremen another group, moulders still another, and so forth. In all, fourteen such broad groupings existed for the machine trades and four with regard to the assembly trades. In short, by further subjecting promotion policies to administratively located rules and procedures, the new agreement marked an important step forward towards the creation of a fully-fledged internal labour market in ITI, despite the management clinging on to criteria such as suitability and merit.

Viewed through the optic of workers' interests, a seniority grid applicable right across the factory presented at least two significant advantages. First, with the axis of mobility being extended from an intra-divisional plane to an interdivisional one, a far more extensive range of opportunities automatically opened up for the workforce. Not only was a Strowger press operator or adjuster now entitled to seek promotion within his trade in the crossbar or transmission division. In order to facilitate optimum career progression, workers also had the right to change trades, even being authorized to cross over from the machine shop to the assembly shop and vice versa, though in all such cases the candidate was required to demonstrate his aptitude for the job by passing a "trade test".

Second, and intimately connected to the above, the modified seniority rules eliminated a major source of friction among older and younger workers by making sure that the claims of long-service workers were no longer ignored. The removal of all restrictions on the mobility of the workforce meant that the earlier practice of a crossbar or transmission division toolsetter with fewer years of service than a Strowger toolsetter superseding him, simply because the latter was barred from applying for a post in crossbar or transmission, could 
not repeat itself in future. As company officials themselves agreed, the new dispensation by redressing the "main and justified grievance" of senior workmen was "logical and fair both to the employees and to the Industry". Notwithstanding its persistent opposition in the past to the introduction of common plant-wide seniority rankings, for fear of its disruptive impact on production plus the higher retraining costs it could involve, the management had come to realize that only a solution of this nature could help to restore industrial peace.

Ironically, in the search for a mutually acceptable compromise, overcoming the resistance of the management might have been a less strenuous task for the union than winning over elements within the union executive and its own membership. By the union's own admission, the dispute over seniority and promotions represented the "most complex and difficult major problem ever faced by [it]", given the divergent interests of different sections of the workforce. In fact, company executives blamed the divisions within the union executive for the leadership's failure to "carry the workers by persuasion [sic]", and urged them to maintain "normal production" while it finalized a fresh seniority protocol. ${ }^{83}$ As one union circular lamented, not only did "each large group [of ...] workers look at the problem from the angle of its own interests"; the interests of one group also often tended to collide with the "interests of another group", therefore considerably complicating things for the union leadership. ${ }^{84} \mathrm{~A}$ few weeks before the conclusion of the agreement, one management document categorically stated that no initiative tabled by the union with respect to seniority "can give complete satisfaction to all the workers in the different divisions [...] in view of (their) conflicting aspirations" ${ }^{85}$

The splits criss-crossing workers' ranks separated them as much along generational lines as along divisional and skill ones. Junior workers by and large preferred to maintain the principle of divisional seniority, as it prevented more senior colleagues from other divisions from pressing their claims for promotion. Much the same applied to crossbar and, to a slightly lesser extent, transmission workers, who benefited from the fact that production volumes in these divisions were expanding at a brisker pace than in Strowger, resulting in the creation of more and higher ranking jobs. Likewise, qualified workers in departments such as machine and plant maintenance and the tool room, where the possibilities for progression were comparatively greater, perceived little advantage in switching over to a classificatory scheme embracing the entire factory as it tended to tilt the scales implicitly in favour of less skilled workers.

82. Minutes of management-union meeting, I9 June 1972.

83. Minutes of I 3 oth meeting of ITI Board of Directors, 9 June 1972.

84. ITI Union Circular, I 8 May 1972.

85. Promotion Policy for Factory Operatives, n.d. [June 1972]. 


\section{INTERNAL LABOUR MARKET CREATED AFTER FRESH LABOUR PROTESTS}

Notwithstanding the implementation of the revised seniority norms, mobility continued to remain a highly contentious issue. After a lull of about five years, signs of unrest soon became visible again. In June I977, declaring that it was under pressure from the rank and file as well as shop delegates to "take a more forceful stand", the union issued the management with an "ultimatum" to introduce rapidly a routinized time-bound promotion scheme. ${ }^{86}$ Under the scheme, workers would automatically progress from one category to the next upon completion of a stipulated number of years of service, without reference to any of the hitherto operative criteria such as seniority, merit, or suitability. Shortly after this ultimatum, the management complained that, despite extensive recourse to overtime work, production and efficiency levels had declined over the previous year in Strowger, crossbar, and telephone divisions. Operatives in these divisions, it declared, had adopted an "agitational approach" and several cases of unauthorized work stoppages had been reported. ${ }^{87}$ Company officials repeated the charge the following month, but the situation seems to have calmed down thereafter.

In December 1977, trouble broke out anew. The protagonists this time were unskilled workers, a group which had derived minimal benefits from the changes effectuated to the company's promotion policies. These workers had typically entered ITI as casual hands before being made permanent, and since they possessed no formal qualifications their chances of progressing up the job ladder were nonexistent. In what had become by now a hardy ritual, nearly 300 sweepers, helpers, attenders, gardeners, labourers, and the like congregated behind the administration building and began shouting slogans. Denouncing the fact that most of them had not received a single promotion even after working for twelve or fourteen years, the workers raised slogans strongly critical of the union leadership, accusing it of neglecting those situated at the bottom-most layer of the occupational hierarchy.

Meanwhile, the union renewed its demand for the implementation of a time-bound promotion programme (TBP). Warning the management that growing dissatisfaction over lack of mobility would impinge on production volumes, union representatives urged the company to follow the lead of other state-owned enterprises such as Bharat Heavy Electricals Ltd and Bharat Electronics Ltd, which had already devised structured career paths for their workforces. ${ }^{88}$ In a strike ballot held in mid-August

86. Minutes of management-union meeting, I4 June 1977.

87. Minutes of management-union meeting, 28 July 1977.

88. Minutes of management-union meeting, 22 November 1978. 
I979, four-fifths of the membership voted in favour of going on strike, an eloquent statement of the rank and file's support for the course of action advocated by the leadership. Exactly a month later the strike got underway and ended nine days later in an emphatic victory for the workers. The management conceded all the demands put forward by the union. As it later admitted, "very negligible" promotion opportunities had "created hardships to a large number of employees [sic]". ${ }^{89}$ Even though implementational and other difficulties continued to fuel unrest in certain pockets for some time, over 3,300 promotions were granted in the very first year that the time-bound promotion scheme was instituted, and an additional 2,057 in 1980 - eloquent proof of just how beneficial this measure was to the workforce. ${ }^{90}$ The conflict in ITI, though, seems to have remained a purely localized and isolated event. We have no information suggesting that the example of workers here succeeded in firing the imagination of their counterparts in other Bangalore-based public or private sector companies, let alone the private sector. ${ }^{9 \mathrm{I}}$

So with the new promotion system in place, the transition to a fully fledged internal labour market whose defining trait was the articulation of careers to a fixed temporal horizon was finally complete. ${ }^{92}$ Where managerial discretion and arbitrariness had conditioned mobility, formally administered mechanisms, enforced by collective agreements, now regulated the entire process: "Under TBP, even the chairman can't recommend somebody for a promotion". ${ }^{93}$ Where some workers could earn two promotions in as many years and others none in ten years, a precisely codified time scale was now developed to determine the

89. Salient Features of TBP Scheme, n.d.

90. PD files. It is worth noting the temporal coincidence between the enshrinement of seniority-based promotion rights in ITI and the progressive repeal in the advanced economies of these same mechanisms, viewed as an obstacle by employers in their aggressive pursuit of "flexibilization".

9I. Whether or not professional mobility was equally contingent on length of service in private firms is something we cannot answer with any certitude, once again due to insufficient research in this area. In his survey, undertaken in the early I970s, of two private and state-owned companies in Bangalore, Holmström, after noting the existence of detailed criteria for promotions, concludes that the overriding factor is seniority. But apart from problems with his data, his conclusion conflicts with workers' own representations. According to them, managerial decisions continued to be ruled by arbitrary considerations and favouritism; South Indian Factory Workers, pp. 54-56.

92. In the context of a "free" competitive market, one consequence of the development of an extensive internal labour market is that labour is transformed from a fully variable factor, subject to unrestricted lay-offs and hirings in response to economic fluctuations, to a quasi-fixed factor. However, because legislation in India made lay-offs virtually impossible, labour was already more or less treated as a quasi-fixed cost by several big private and public enterprises, including ITI.

93. Interview, Govindaraju. 
movement from one category to the next. Depending upon the promotion channel into which a worker was slotted, which in turn was related to the content of his/her work task and level of education, the waiting period for advancement varied from six to eight years; ${ }^{94}$ subsequently, this qualifying span would be reduced by one year for all employees. Only a poor disciplinary record could postpone, though not halt, the climb up the job ladder. Employees punished for serious infractions saw their promotions delayed by two years, and those punished for minor infractions by one year; subsequently, these conditions too were relaxed.

To be sure, by bestowing rewards on "sincere and lazy" workers alike, the new procedures attracted criticism, especially from those sections of the workforce disappointed at having failed to realize higher dividends from their educational capital. ${ }^{95}$ As one disgruntled computer technician declared, "when I see a lazy employee being automatically promoted I get frustrated [...]. If you are good, you should get promotions based on merit". ${ }^{96}$ Echoing a similar view, another qualified worker lamented that he had "lost all opportunity to show my skills, improve my status and build a career because of TBP [...]. There are no incentives for or recognition of the skills of qualified workers [...]. TBP has brought an end to the differences between non-qualified and qualified workers." 97 But such sentiments were confined to a small minority; without losing sight of its shortcomings most of the workers whom we interviewed enthusiastically endorsed the TBP as a positive achievement. What they appreciated above all was the freedom from managerial caprice and, its logical corollary, the fairness that it ensured, as the following quotations underscore.

Everybody now has a chance to get promotions regularly. Otherwise, if you join as a operator, you will continue as a operator until the end. ${ }^{98}$

Educated and uneducated workers, good and bad workers, all now have a chance of getting regular promotion. This is good because there is no partiality

94. Two classificatory exercises underpinned the time bound promotion scheme. First, employees were distributed across three broad categories: technical operative, technical nonoperative, and non-technical. The first category covered all blue-collar occupations both within and outside the shopfloor, the second category merged personnel such as planners, draughtsmen, and technicians, and the third mainly clerical jobs. Then, on the basis of their jobs and formal qualifications, employees in each category were accommodated into one of the ten promotion channels that had been created. Thus while channels one to three regrouped all technical operative personnel, channel one consisted exclusively of unskilled or low skilled workers, channel two of semi-skilled workers, and channel three of skilled workers.

95. Interview, Vadiraj Hatwar, November-December 1997.

96. Ibid. Some of the workers interviewed by Holmström voiced an identical grievance; South Indian Factory Workers, pp. IоI-I I I.

97. Interview, R. Paneerselvam, 27 October 1997.

98. Interview, Anantha Padmanabha, I December $200 \mathrm{I}$. 
now, no chance of jealousy. Before management used to show a lot of discrimination and favouritism. ${ }^{99}$

You can't help the fact that good and bad workers get promotion under TBP. Before we were never getting promotions. It is true that there is no reward now for good workers. That is an anomaly in the scheme which the management and the union should solve. ${ }^{\text {I00 }}$

TBP is good in one way, because it removes the chances of stagnation. The bad aspect is that workers become lazy. As long as their attendance is regular, everybody is sure to get promotion whether he works or not. ${ }^{\text {IOI }}$

Greeted with enthusiasm by the majority of the workforce, the revised promotion plan would, however, evoke a hostile response from one quarter, the ITI Scheduled Castes (SC) and Scheduled Tribes (ST) Employees' Association. This body had been formed in 1975 to safeguard the rights of the "Untouchables" by ensuring that the company conformed to the government directive reserving a certain percentage of jobs in the public sector, as part of the broader affirmative action programme, for the socioeconomic amelioration of these disadvantaged groups. ${ }^{102}$ The association was not legally entitled to represent the interests of SC-ST employees who together accounted for around one-fifth of the total workforce of I9,500 employees in 1980. Nevertheless, on most non-contractual issues, the management and the main union had conceded to it the monopoly to speak on behalf of its constituents.

The principal complaint levelled by the association at the TBP touched on the fact that it had abolished the principle of reservations in promotions since everybody was now assured of vertical mobility. It must be noted that quotas for SC-ST employees did not merely cover entry-level recruitments. They also extended to promotions with is per cent of promotions in all categories being earmarked for the Scheduled Castes and 7.5 per cent for the Scheduled Tribes. Protesting against the end of promotion reservations, the association challenged the constitutional validity of the TBP before the courts.

In turn, the management argued that the government had endorsed its stand that automatic promotions rendered quotas here superfluous. ${ }^{103} \mathrm{It}$ also subsequently pointed out that the TBP had procured substantially greater benefits for SC-ST employees, and workers in general, than would

99. Interview, Vinayagam.

I00. Interview, Krishnan, 3 November 2001.

IоI. Interview, Sahadevan, 6 May 1999.

I02. In ITI all executive posts were earmarked to the order of I 6.7 per cent for the Scheduled Castes and 7.5 per cent for the Scheduled Tribes. In the case of non-executive posts, quotas for the SC stood at I 3 per cent (later hiked to I 5 per cent) and for the ST at 5 per cent. I03. Ref. No. 6(7)/80-BPE (GM-I) SC-ST Cell, 8 March I983; OM No.6/27/85-BPE (SC/STCell), 29 June 1987. 
have been the case had the scheme not existed. Going by the company's calculations, between 1979 and 1987 SC-ST employees received over 4,000 promotions or 20 per cent of the total, whereas under the earlier dispensation the figure would not have exceeded $500 .{ }^{104}$

These statistics conveniently glossed over two crucial points. First, barely 3 per cent of all non-officers who had risen to officer ranks belonged to the "Untouchable" communities. Second, their share of promotions to the highest worker grades failed to exceed i per cent. ${ }^{\text {IOS }}$ In other words, SC-ST beneficiaries of the TBP consisted in the main of lower-category employees, thus confirming the association's misgivings about the new dispensation.

The legal guerrilla war waged between the SC-ST association on the one hand, and the management, backed by the union, on the other would drag on for over two decades. The union's decision to join forces with the management stemmed from fears that a failure to involve itself would be interpreted as a sign of lack of interest by the judiciary and incite it to "freeze" the TBP. The validity of this contention is hardly questionable. In acting to protect the new promotion plan, which contained the promise of offering both monetary and status incentives to large numbers of individuals, workers' representatives were, no doubt, swayed by laudable motives by which minority claims, regardless of their worth, had to be sacrificed at the altar of the greater good.

Nevertheless, the union's appearance as a litigant alongside the company would have the effect of further embittering relations between it and the SC-ST association. It would also project, rightly or wrongly, an image of the union as a "casteist" body, intent above all in championing majoritarian interests, which in this case also turned out to be the dominant interests. Conversely, the SC-ST association's efforts to derail the automatic promotion scheme served to stoke to a higher pitch the animosities of caste Hindu workers, already deeply resentful of the entire gamut of compensatory discrimination measures enacted by the Indian state, and to harden the lines of difference between them and their SC-ST colleagues.

\section{PROMOTIONS FETCH HIGHER PAY BUT NO NEW RESPONSIBILITIES}

If the principle of automatic promotions assured ITI workers of steady upward advancement, for the company it held out the possibility of greater flexibility in the deployment of labour. Despite having initially dragged its feet about overhauling the company's promotion policies,

104. Barring 1982, when I 5.2 per cent of all promotions went to SC and ST employees, in no other year did their share drop below i 8.5 per cent; PD files.

I05. Karnataka High Court ruling on writ petition No. 5700/1980 and writ petitions Nos. 4916-49I8/1980, I 2 January I990. The figures are for the period I979 to 1989. 
officials soon understood that conceding this specific demand of the union could also serve its own ends. In a note to the ITI board of directors, justifying the decision to implement the TBP, which in effect amounted to relinquishing an essential managerial prerogative, that of evaluating selected individuals and conferring scarce rewards on them, the management cited reasons of technical efficiency.

At a time when the company faced "drastic technological changes", occasioned by the phasing out of the old electro-mechanical exchanges, the new arrangements were viewed as allowing it better to adjust to these changes by facilitating the rotation of personnel and the allocation of multiple tasks, as well as removing restrictions on internal transfers. ${ }^{106}$ To enable a person to perform a range of jobs calling for different skills, the company also agreed to provide on-the-job or specialized training. But no such initiatives materialized, foiling plans to foster functional flexibility and worker polyvalence. As one internal memo dated i985 observed, frustration was growing among lower-level employees because the nature of their jobs remained identical even after moving to a higher grade, thus depriving them of opportunities to acquire fresh skills. ${ }^{107}$

This statement clearly attested to the failure of the company to develop the right kinds of training programmes. Furthermore, low-ranking employees were not the only groups to find themselves bound in an occupational straitjacket. Notwithstanding the official rhetoric about the new promotion scheme "provid(ing) scope for job enrichment", a combination of minimal turnover, insufficient work loads, and the absence of training meant that semiskilled and skilled workers too were condemned to continue doing the same job despite receiving promotions. ${ }^{108}$ To quote one machine tender who rose to become an officer, "though I am an assistant engineer today, I am not in charge of any group or department. There is no change in my job with TBP, only monetary benefits [...]. Before TBP, an assistant engineer was a very powerful man." ${ }^{\circ}$ In other words, a pronounced disjunction existed between the nominal and the real, between the title and the function or the job. ${ }^{\text {Io }}$

By emptying the job of most of its signification, the material rewards attached to the title bore minimal correspondence with its symbolic rewards. So to the extent that the internal labour market in ITI offered workers very little prospect of occupational change and upgrading of their skill base and responsibilities, it represented a significant deviation from the textbook

106. Note to ITI Board, I80th meeting, Item No. Bio, August I98 I.

107. PD file, DMT/32 A, 9 October 1985.

I08. Memorandum of Settlement, 4 November 1985.

I09. Interview, Ravindranath, 7 January 1998.

ı Iо. Pierre Bourdieu and Luc Boltanski, "Le titre et le poste, rapports entre le système de production et le système de reproduction”, Actes de la Recherche en sciences sociales, 2 (1975), pp. $95-107,95$. 
model, which stressed the importance of these aspects in ensuring the efficient functioning of this institution. ${ }^{\text {II }}$ In such a context, the definition of professional mobility took on a highly restrictive meaning. It only signified higher money wages, while excluding the possibility of expanding skills, qualifications, and experiences.

\section{CONCLUSION}

To conclude, this paper challenges orthodox and radical theses of internal labour markets which, we contend, have failed sufficiently to acknowledge the complex and polymorphous dimension of this institution. The tendency to conceptualize formalized employment practices as arising from or being shaped by the unilateral action of employers aspiring for greater technical efficiency has resulted in radical scholars in particular, totally minimizing the role played by workers in this process. As against this position, we have demonstrated that the establishment of a regulatory framework to administer seniority and promotion rights at ITI derived its impetus exclusively from the collective endeavours and tenacity of employees, who often acted autonomously of the union. One could plausibly argue that such regulations created the objective preconditions for "manufacturing consent" to the existing social relations of production. But this is to forget that they were also instrumental in imposing constraints on managerial discretion and in empowering workers as industrial citizens, endowed with a series of clearly defined rights and obligations.

At the same time, this paper has revealed the paradoxical character of occupational mobility, a force at once capable of unifying and dividing the workforce. A highly evocative symbol of self-dignity and equity, seniority norms and promotions contain the potential for mobilizing the entire workforce, even as they give rise to a gamut of conflicting interpretations in function of the specific interests and aspirations of different generational and professional groups. Universal in its appeal, career advancement is thus, by definition, particularistic and plural in its meaning, given the inherently stratified nature of the work place.

From the standpoint of the union, this Janus-like attribute of promotions poses considerable difficulties, compelling it to perform a delicate balancing act as it mediates between a welter of claims and counterclaims. Representative of the general interests of the workforce, the union cannot be seen to privilege the sectional demands of any particular group, however vocal or strong this group may be, if it is to preserve the unity and cohesion of the organization and the positions of its officials. Considerations of greater good have to take precedence over minority claims. internes, marchés externes", Revue économique, 40 (1989), pp. 273-328. 